\title{
Biological evaluation of 8-alkyl xanthines as potential cytotoxic agents
}

\author{
Renuka Suravajhala $^{1^{* \#}, \text { Nitasha Suri }^{2 *} \text {, Madhulika Bhagat }}{ }^{3}$, Ajit Kumar Saxena $^{2 \#}$ \\ ${ }^{1}$ Department of Science, Systems and Models, Roskilde University, Roskilde, Denmark \\ ${ }^{2}$ Cancer Pharmacology Division, Indian Institute of Integrative Medicine, Jammu, India \\ ${ }^{3}$ Department of Biotechnology, Jammu University, Jammu, India \\ Email: ${ }^{\text {renu@,ruc.dk, }}, \underline{\text { aksaxena@,iiim.res.in }}$
}

Received 4 March 2013; revised 29 April 2013; accepted 15 May 2013

Copyright (C) 2013 Renuka Suravajhala et al. This is an open access article distributed under the Creative Commons Attribution License, which permits unrestricted use, distribution, and reproduction in any medium, provided the original work is properly cited.

\begin{abstract}
A series of 8-substituted alkyl xanthines were evaluated in vitro to test the cytotoxocity in cells. For this experiment, we utilized different mammalian cancer cell lines primarily representing prostrate and lung. One of the compounds synthesized, viz. 8-tertbutyl caffeine showed potent anticancer activity at low concentrations against DU145 when compared to adriamycin. Further experiments were carried out to check the cell cycle arrest in the DU145 cells treated with adriamycin, caffeine and 8-tert butyl caffeine. We observed that there was an arrest in G1 phase of cell cycle at $\mathbf{2 4}$ hours while at $\mathbf{4 8}$ hours of incubation, the cells were constantly distributed $(59.71 \%-70.79 \%)$. We conclude that the effect of 8-tertbutyl caffeine is relatively comparable to caffeine whereas in adriamycin treated cells, we observed the cells underwent G2 arrest. We evaluate the studies on these effects by showing potent analogues which could be used as promising anticancer agents.
\end{abstract}

Keywords: 8-Substituted Alkyl Xanthines; Cytotoxicity; Anticancer Agents

\section{INTRODUCTION}

Xanthines are purine bases which are known to act as anti-depressants, anti-therapeutic and anti-hyperuraemic agents. Found in human tissues and fluids, some xanthines play a role as bronchodilators, diuretics, natriuretics, analgesic adjuvants and lipolytics. More recent studies on xanthines have shown that these are sensitive in irradiating tumor cells inhibiting G2 checkpoint [1], furthering cells to become more sensitive to DNA dama-

\footnotetext{
*Equal contributing authors

\#Corresponding authors.
}

ge. The best example of xanthine is caffeine, known to be involved in human carcinogenesis at various sites of the tumors. These studies on caffeine have shown to enhance the cytocidal and growth inhibitory effect suggesting that caffeine may be useful in enhancing the tumoricidal effect of anticancer drugs, especially DNAdamaging agents, and possibly aid in overcoming natural drug resistance. In the recent-past, studies on xanthines have resulted in several cancer studies. For example, human adenocarcinoma cell line (A-549) was derived from a primary lung cancer expressing wild-type p53 [2]. Studies on abnormalities of the p53 gene function has shown more impact on cancers including tumors of the breast, lung, colon, bladder, brain, bone, hematopoietic, and muscle tissues [3]. Prostate cancer, a slow growing latent cancer, plays a major role in carcinogenesis. Caffeine products such as tea are studied with respect to promotion and progression stages of carcinogenesis. This is thought to be largely due to inhibition of cellular proliferation and induction of apoptosis. Less number of prostate cell lines are available and have been derived from metastatic tissue and not from primary tumours. The only cell line, LNCaP is androgen dependent while DU145 and PC-3 are androgen independent. The metastatic origin and androgen independence in well established prostate cell lines are major limiting factors. DU145 and PC-3 possess different genotypes and growth characteristics. Both are androgen independent. PC-3 is p53null but expresses the functional $\mathrm{Rb}$ protein whereas DU145 cells express mutant $\mathrm{p} 53$ and are $\mathrm{Rb}$ protein negative [4]. The treatment of localization of prostate cancer by radiotherapy is an attractive alternative to surgery as it leads to fewer complications. Studies show that DNA damage with drugs were demonstrated for DU145, BM1604 and LNCaP cells that enhanced sensitivity to cisplatin, vinblastine and etoposide leading to G2 block [5]. It was first shown that in A-549 p53 trans- 
fectants, the radiosensitization by methyl xanthines operates more effectively in $\mathrm{p} 53$ mutant than in $\mathrm{p} 53$ wild type cells [6]. Furthermore, it was shown that caffeine $(2.5 \mathrm{mM})$ treatment reversed the adriamycin inducing $\mathrm{Cdc} 2$ and apoptosis in cells arrested at G2 phase of the cell cycle [7]. The induced apoptosis in numerous colorectal and prostate cancer cell lines were HCT116p53 wildtype; HCT116 — p53 deleted; SW480 - p53 mutant; DLD-1—p53 mutant; CCD-18Co-p53 wildtype; DU145 prostate - p53 mutant; LnCAP - p53 wildtype/ PTEN mutant with variable p53 expression. Evidences show that pentoxifylline and caffeine play a major role in p53 mutant and p53 defective cells sensitized to irradiation mechanism for selective targeting of tumor cells [8]. Further, these studies have also shown that irradiated cells blocked in G2 phase would progress into early mitosis and G1 phase thus shortening the repair time. Irradiation make cells to block G2 phase followed by cytostatic drugs treated with a non-toxic dose such as pentoxifylline inviting the cells into mitosis and change repair mode. When wild-type p53 cells are damaged by irradiation, the increase of $\mathrm{p} 53$ protein causes a G1 arrest and cells undergo repair or apoptosis [9]. The p53 mutant cells present in the majority of tumours show G2 cell cycle arrest facilitating DNA repair further preventing the propagation of the defective genome to daughter cells [10]. In p53 wild-type cells, arrest in G1 can allow cells to undergo repair. This leads to cell survival and by $\mathrm{p} 53$ induction, it undergoes apoptosis and cell death. No further studies have been carried out on the role and efficacy of substituted xanthines in various cancer cell lines. Keeping in view of this, we aimed to evaluate the effect of 8-alkyl xanthines as potential cytotoxic agents.

\section{MATERIALS AND METHODS}

\subsection{Cancer Cell Lines}

Human colon (HCT-15, CoLo-205), lung (A-549, HOP$62)$ and prostrate (PC-3 and DU145) cancer cell lines (from National Cancer Institute, Fredrick, USA and National Center for Cell Science, Pune, India), FCS $(10 \%)$, penicillin (100 units $/ \mathrm{ml})$, streptomycin $(100 \mathrm{~g} / \mathrm{ml})$, glutamine $(2 \mathrm{mM})$ and $\mathrm{CO}_{2}$ incubator (Heraeus, $\mathrm{GmbH}$, Germany), ELISA reader (Thermo Multiscan Spectrum).

\subsection{In vitro Cytotoxicity Studies}

The human colon (HCT-15, CoLo-205), lung (A-549, HOP-62) and prostrate (PC-3 and DU145) cell lines were grown and maintained in RPMI-1640 medium, $\mathrm{pH} 7.4$, whereas DMEM was used for Neuroblastoma (IMR-32), CNS (SNB-78) and liver (Hep-2). The media was supplemented with FCS $(10 \%)$, penicillin $(100$ units $/ \mathrm{ml})$, streptomycin $(100 \mathrm{~g} / \mathrm{ml})$, glutamine $(2 \mathrm{mM})$ and cells were grown in $\mathrm{CO}_{2}$ incubator (Heraeus, $\mathrm{GmbH}$, Ger- many) at $37^{\circ} \mathrm{C}$ with $90 \%$ humidity and $5 \% \mathrm{CO}_{2}$. Cytotoxicity against various human cancer cell lines was determined [11] in vitro using 96-well tissue culture plates. The $100 \mathrm{~mL}$ of cell suspension was added to each well of the 96-well tissue culture plates. The cells were allowed to grow in $\mathrm{CO}_{2}$ incubator $\left(37^{\circ} \mathrm{C}, 5 \% \mathrm{CO}_{2}, 90 \%\right.$ $\mathrm{RH})$ for 24 hours. The test materials were in complete growth medium $(100 \mathrm{~mL})$ in a carbondioxide incubator. After addition of test materials, the cell growth was stopped by gently layering trichloroacetic acid $(50 \%$ TCA, $50 \mathrm{~mL}$ ) on top of the medium in all the wells. A set of 8-alkyl xanthines were assayed in vitro cytotoxicity with human cancer cell lines, viz. prostrate (PC-3, DU145), cervix (Hela), ovary (IGR-OV-1), colon (HCT15, CoLo-205 ), leukemia (THP-1), lung (A-549, HOP62 ) using sulforhodamine B. The cells were allowed to proliferate in presence of test material for 48 hours at a concentration of $(0.5 \mathrm{mM}-1.5 \mathrm{mM})$. The plates were incubated at $4{ }^{\circ} \mathrm{C}$ for one hour to fix the cells, and after 24 hours incubation to the wells containing cell suspension. The plates were further incubated for 48 hours $\left(37^{\circ} \mathrm{C}\right.$ in an atmosphere of $5 \% \mathrm{CO}_{2}$ and $90 \%$ relative humidity) and the cells were attached to the bottom of the wells. The liquid of all the wells was gently pipetted out and discarded. The plates were washed five times with distilled water to remove TCA, growth medium lowering molecular weight metabolites, serum proteins etc. and then air-dried. Cell growth was measured by staining with sulforhodamine B dye. The adsorbed dye was later dissolved in tris- $\mathrm{HCl}$ Buffer $(100 \mathrm{~mL}, 0.01 \mathrm{M}, \mathrm{pH} 10.4)$ and plates were gently stirred for $10 \mathrm{~min}$ on a mechanical stirrer. The optical density (OD) was recorded on ELISA reader at $540 \mathrm{~nm}$.

\subsection{Cell Cycle Analysis with Flow Cytometry}

The DU145 cells have been seeded with 106 cells in 92-mm cell culture dish (for 8-alkyl xanthine treatment). After 48 hours of incubation, cells were treated with 1.5 $\mathrm{mM}$ of 8-tertbutyl caffeine at $37^{\circ} \mathrm{C}$ and $5 \% \mathrm{CO}_{2}$. After treatment, the cells were grown in 10\% FBS-containing culture medium for 6, 24, 48, 72 and 96 hours. Attached cells were harvested by trypsin treatment and pooled with detached cells from the growth medium. Cells were pelleted by centrifugation at $200 \times \mathrm{g}$ for $5 \mathrm{~min}$, washed twice with PBS and $5 \times 10^{5}$ cells were resuspended in $200-\mu \mathrm{l}$ PBS and fixed in 2-ml ice-cold 70\% ethanol. The cells were left on ice for at least $30 \mathrm{~min}$ and kept at $-20^{\circ} \mathrm{C}$ until analysis by flow cytometry. Cells were centrifuged at $300 \times \mathrm{g}$ for $5 \mathrm{~min}$, washed with PBS, treated with $0.1 \mathrm{mg} / \mathrm{ml}$ RNase A (Pharmacia), and stained with $40 \mu \mathrm{g} / \mathrm{ml}$ propidium iodide (Sigma) in a final volume of $500 \mu$ l. The cells were incubated for at least 30 min at room temperature. Cell content was determined using Becton Dickinson fluorescence-activated cell 
sorter (FACS) calibur and Cell Quest software. At least 104 cells were measured for each sample.

\section{RESULTS AND DISCUSSION}

The present studies revealed that a set of 8-substituted alkyl xanthines exhibited cytotoxicity on wide range of human cancer cell lines. We observed that the compounds, viz. 1a, 1c, 2a, 2c, 3a, 3c, 4c, 5a, 5c (Figure 1) showed potential cytotoxicity effect especially on PC-3, DU145 (prostate), HOP-62 (lung), COLO-205 (colon) cell lines (Table 1). Interestingly, 8-isopropyl-3-isobutyl -1-methyl-theophylline (compound 4a) did not show potential cytotoxicity on these cell lines. It may be due to steric hindrance exhibited by the compound with low concentration. Whereas 8-tertbutyl caffeine (compound 1a) is also known to exhibit steric hindrance but showed potential cytotoxic effect because of less steric hindrance at $\mathrm{N} 1$ region of 8-tertbutyl caffeine, when compared to 8-isopropyl-3-isobutyl-1-methyl-theophylline. However, the compounds could not show remarkable cytotoxicity effect in other cancer cell lines, viz. leukemia, cervix and ovarian cell lines suggesting that they may not be suitable anticancer agents for these cell lines. This is in agreement with adriamycin which showed more or less the same effect on these cell lines.

Furthermore, the compounds we synthesized have shown effective cytoxicity on prostrate, lung and colon cancer cell lines suggesting that these compounds may<smiles>[R]NCC(=O)ON</smiles><smiles>[R]c1nc2c(c(=O)n([R])c(=O)n2[R])n1[R]</smiles>

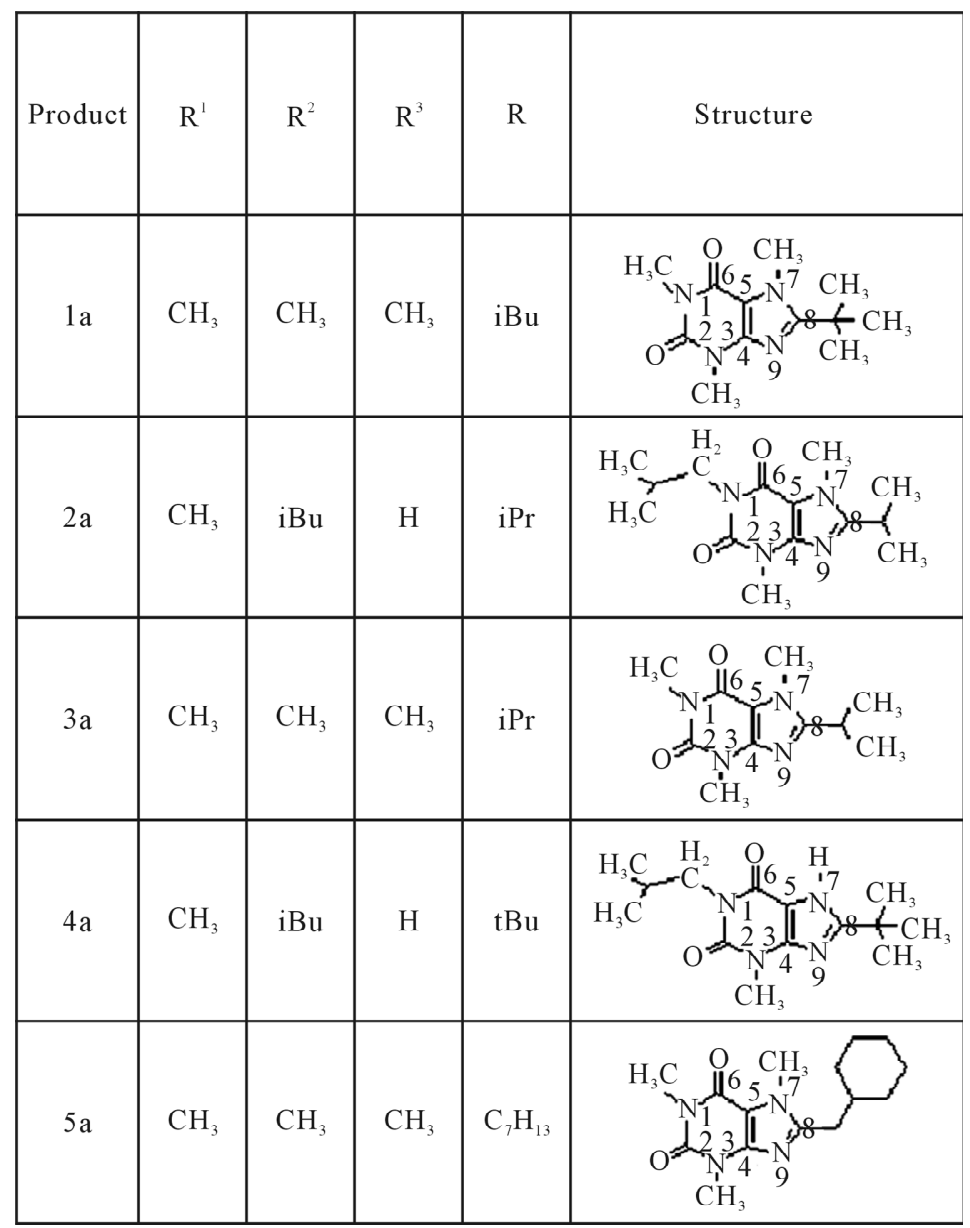

Figure 1. 8-substituted alkyl xanthines synthesized: (1a) 8-tertbutylcaffeine, (2a) 8-isopropyl-3-isobutyl-1-methyltheophylline, (3a) 8-isopropyl caffeine, (4a) 8-tertbutyl-3-isobutyl-1-methyl-theophylline, (5a) 8-cyclo-hexyl caffeine. 
Table 1. Evaluation of anticancer activity of synthesized 8-substituted alkyl xanthines (with $0.5 \mathrm{mM}-1.5 \mathrm{mM}$ concentration). Five different compounds, viz. 1a, 2a, 3a, 4a and 5a have been with treated with a concentration of $1 \mathrm{mM}$. Each compound has been further treated with increase in concentration of $1.1 \mathrm{mM}$ and $1.5 \mathrm{mM}$. For instance, the compound 1a has increased concentration in the name of $1 \mathrm{~b}$ and $1 \mathrm{c}$ for $1.1 \mathrm{mM}$ and $1.5 \mathrm{mM}$ respectively. The same method has been employed for other four compounds $2 \mathrm{a}, 2 \mathrm{~b}$ and $2 \mathrm{c} ; 3 \mathrm{a}, 3 \mathrm{~b}$ and $3 \mathrm{c} ; 4 \mathrm{a}, 4 \mathrm{~b}$ and $4 \mathrm{c} ; 5 \mathrm{a}, 5 \mathrm{~b}$ and $5 \mathrm{c}$. A set of two concentrations for adriamycin (as a control) with $0.5 \mathrm{mM}$ and 0.1 $\mathrm{mM}$ were taken for this experiment.

\begin{tabular}{|c|c|c|c|c|c|c|c|c|c|c|}
\hline \multirow{3}{*}{ Compounds Tested } & \multirow{3}{*}{ conc } & \multicolumn{9}{|c|}{$\%$ growth inhibition } \\
\hline & & \multicolumn{2}{|c|}{ Prostate } & \multicolumn{2}{|c|}{ Lung } & \multicolumn{2}{|c|}{ Colon } & \multirow{2}{*}{$\begin{array}{c}\text { Leukameia } \\
\text { THP-1 }\end{array}$} & \multirow{2}{*}{$\begin{array}{c}\text { Cervix } \\
\text { Hela }\end{array}$} & \multirow{2}{*}{$\frac{\text { Ovary }}{\text { IGR-OV-1 }}$} \\
\hline & & PC-3 & DU-143 & A-549 & HOP-62 & COLO-205 & HCT-15 & & & \\
\hline 1a & 1 & 51 & 64 & 30 & 67 & 34 & 12 & 11 & 3 & 27 \\
\hline $1 b$ & 1.1 & 2 & 0 & 19 & 0 & 0 & 5 & 32 & 23 & 33 \\
\hline $1 \mathrm{c}$ & 1.5 & 61 & 86 & 36 & 71 & 27 & 0 & 0 & 0 & 0 \\
\hline $2 \mathrm{a}$ & 1 & 52 & 64 & 14 & 51 & 49 & 15 & 34 & 0 & 19 \\
\hline $2 b$ & 1.1 & 7 & 0 & 53 & 0 & 0 & 39 & 43 & 23 & 32 \\
\hline $2 \mathrm{c}$ & 1.5 & 60 & 83 & 34 & 73 & 75 & 0 & 0 & 0 & 0 \\
\hline $3 a$ & 1 & 50 & 59 & 23 & 62 & 54 & 24 & 57 & 10 & 30 \\
\hline $3 b$ & 1.1 & 4 & 0 & 73 & 0 & 0 & 57 & 33 & 13 & 24 \\
\hline $3 c$ & 1.5 & 49 & 87 & 33 & 72 & 10 & 0 & 0 & 0 & 0 \\
\hline $4 a$ & 1 & 47 & 42 & 39 & 72 & 31 & 1 & 25 & 0 & 0 \\
\hline $4 b$ & 1.1 & 20 & 0 & 44 & 0 & 0 & 7 & 29 & 14 & 4 \\
\hline $4 c$ & 1.5 & 58 & 72 & 59 & 72 & 36 & 0 & 0 & 0 & 0 \\
\hline $5 \mathrm{a}$ & 1 & 53 & 53 & 41 & 64 & 29 & 0 & 17 & 0 & 0 \\
\hline $5 b$ & 1.1 & 10 & 0 & 36 & 0 & 0 & 18 & 29 & 7 & 8 \\
\hline $5 c$ & 1.5 & 58 & 66 & 50 & 73 & 52 & 0 & 0 & 0 & 0 \\
\hline Adr & 0.5 & 45 & 81 & 22 & 69 & 31 & 0 & 0 & 0 & 0 \\
\hline Adr & 0.1 & 11 & 0 & 22 & 0 & 0 & 5 & 49 & 31 & 31 \\
\hline
\end{tabular}

act as effective anticancer agents, similar to that of adriamycin. Considering the fact that 8-tertbutyl caffeine (compound 1a) is known to have less steric hindrance, we determined whether or not there is a cell cycle arrest. To determine this, we used DU145 cells treated with 8-tertbutyl caffeine. Cell cycle arrest can occur in either G1 phase or G2 phase of the cell cycle involving certain distinct events. So, we analysed at which phase of the cell cycle, the arrest occured. Previously, we investigated that adriamycin was capable of arresting G1 phase (figure not shown) which is in agreement with erstwhile published reports with various cell lines [12,13]. The FACS analysis on cancer cell line DU145 when treated with 8-tertbutyl caffeine (concentration of $1.5 \mathrm{mM}$ for at $12,24,36$ and $48 \mathrm{hrs}$ ) showed remarkable decrease in G2 phase because the cells are known to be involved in sensitization of p53 proteins. From the FACS analysis, we observe from Figure 2(a), there is an arrest of cells in G1 phase rather in G2 phase of cell cycle, as evident from decrease in number of cells from G1 to G2 (51.28\% to $17.48 \%$ respectively). Likewise, we could see drastic decrease of cells in G2 phase (Figures 2(b)-(d)) which indicates that there is a possibility of repair in G1 phase. This suggests that 8-tertbutyl caffeine can also be used as sensitizers in DNA repair.

\section{CONCLUSIONS}

From 8-aklyl xanthines we synthesized, we believe that the compounds viz. 1a, 1c, 2a, 2c, 3a, 3c, 4c, 5a, 5c with varying concentrations ( $1 \mathrm{mM}, 1.1 \mathrm{mM}$ and $1.5 \mathrm{mM})$ play an important role as cytotoxic agents. Among these compounds, we consider 8-tertbutyl caffeine as a candidate for treating DU145 cells because it is shown to have more cytotoxicity effect compared to the other compounds. We also envisage that along with the group of substituents, selectivity, solubility and stereochemistry of the molecule seem to play a major role for the 


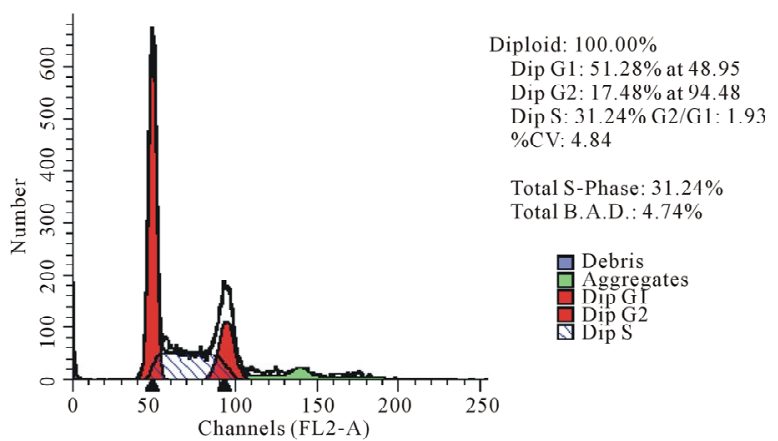

(a)

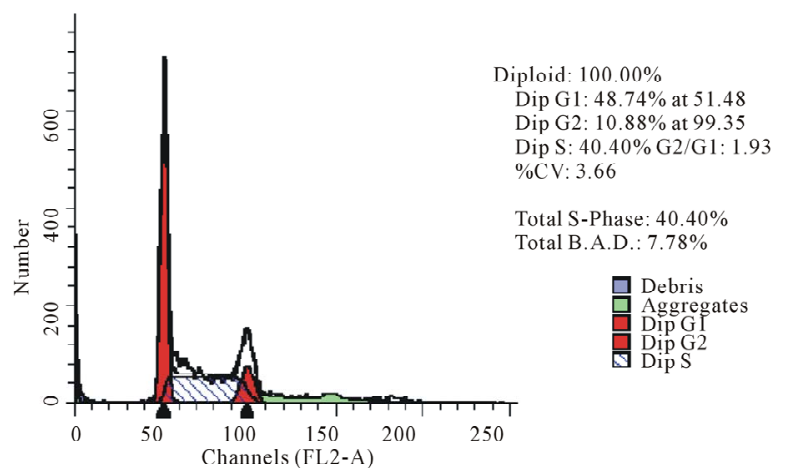

(b)

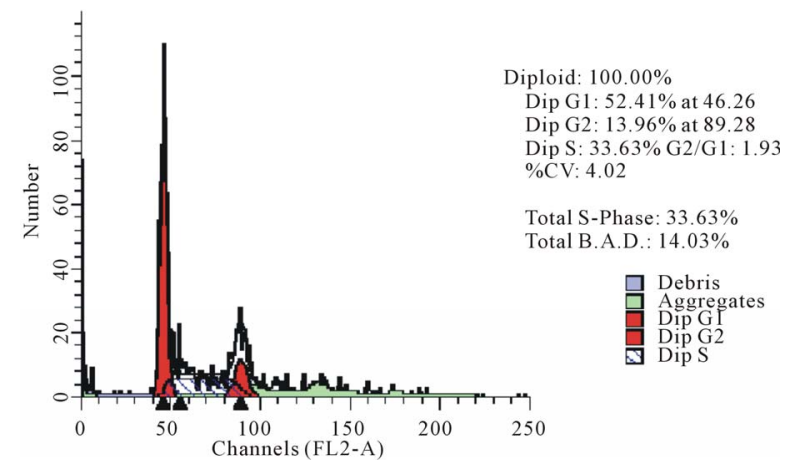

(c)

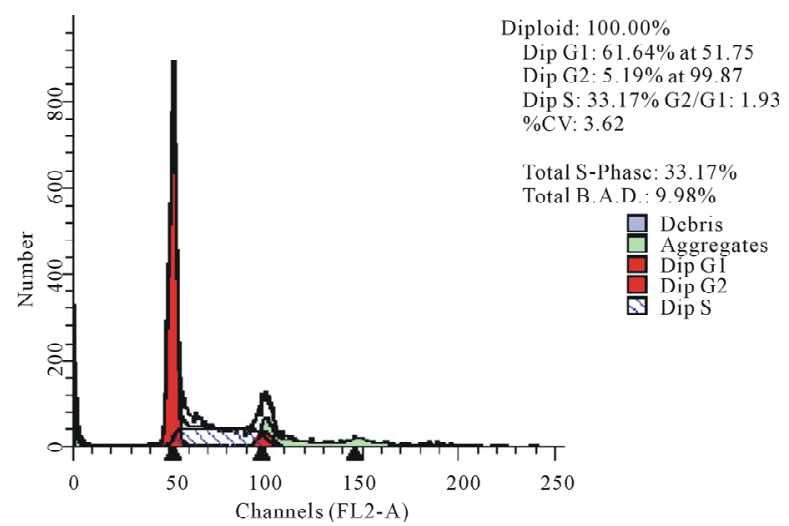

(d)

Figure 2. The FACS analyses of DU145 cell line treated with 8-tertbutyl caffeine (1.5 mM at $12 \mathrm{~h}, 24 \mathrm{~h}, 36 \mathrm{~h}$ and $48 \mathrm{~h})$ showing relative decrease in G2 phase (Figures 2(a)-(d) respectively). cytotoxicity effect. As far as the FACS analysis of the cell lines treated with 8-tertbutyl caffeine is concerned, the growth seems to be asynchronous which induces a predominantly G1 cell cycle arrest. The reason why DU145 cells were arrested in G1 phase could perhaps be due to correlating with the increase of $\mathrm{p} 53$ protein. The relative predominance of $\mathrm{G} 1$ arrest when compared to G2 cell cycle may be due to the aftermath effects of 8tertbutyl caffeine treatment in mammalian cells. Studies on future evaluation of the potent analogues of 8-substituted xanthines can be done while there is a good chance of using them as promising anticancer agents.

\section{ACKNOWLEDGEMENTS}

The authors are grateful to the Pharmacology division, IIIM, Jammu for providing the lab space in carrying out the analysis. We thank Pauli Kofod and Sharmila Bapat for assistance in preparation of 8-alkyly xanthines and cell lines respectively.

\section{REFERENCES}

[1] Tenzer, A. and Pruschy, M. (2003) Potentiation of DNAdamage-induced cytotoxicity by G2checkpoint abrogators. Current Medicinal Chemistry-Anti-Cancer Agents, 3, 35-46. doi:10.2174/1568011033353533

[2] Lehman, T.A., Bennett, W.P., Metcalf, R.A., Welsh, J.A., Ecker, J., Modali, R.V., Ullrich, S., Romano, J.W., Appella, E. and Testa, J.R. (1991) p53 mutations, ras mutations, and p53-heat shock 70 protein complexes in human lung carcinoma cell lines. Cancer Research, 51, 40904096.

[3] Kastan, M.B., Onyekwere, O., Sidransky, D., Vogelstein, B. and Craig, R.W. (1991) Participation of p53 protein in the cellular response to DNA damage. Cancer Research, 51, 6304-6311

[4] Lee, J.M. and Bernstein, A. (1995) Apoptosis, cancer and the p53 tumour suppressor gene. Cancer and Metastasis Reviews, 14, 149-161. doi:10.1007/BF00665797

[5] Serafin, A.M., Akudugu, J.M. and Böhm, L. (2003) Studies on the influence of DNA repair on radio-sensitivity in prostate cell lines. Urological Research, 31, $227-$ 231. doi:10.1007/s00240-003-0299-0

[6] Katsuro, T. and Hiroyuki, T. (1989) Caffeine enhancement of the effect of anticancer agents on human sarcoma cells. Cancer Science, 80, 83-88. doi:10.1111/j.1349-7006.1989.tb02249.x

[7] Saito, Y., Gopalan, B., Mhashilkar, A.M., Roth, J.A., Chada, S., Zumstein, L. and Ramesh, R. (2003) Adenovirus-mediated PTEN treatment combined with caffeine produces a synergistic therapeutic effect in colorectal cancer cells. Cancer Gene Therapy, 10, 803-813. doi:10.1038/sj.cgt. 7700644

[8] Maity, A., Kao, G.D., Muschel, R.J. and McKenna, W.G. (1997) Potential molecular targets for manipulating the radiation response. International Journal of Radiation Oncology, Biology, Physics, 37, 639-653. 


\section{doi:10.1016/S0360-3016(96)00598-6}

[9] Zhu, W.Y. and Melera, P.W. (2001) Levels of metallothionein I and II expression in mouse embryo broblasts enhance growth in low folate through a cell cycle mediated pathway. Cell Biology, 21, 1261.

[10] Russell, K.J., Wiens, L.W., Demers, G.W., Galloway, D.A., Plon, S.E. and Groudine, M. (1995) Abrogation of the $\mathrm{G} 2$ checkpoint results in differential radiosensitization of G1 checkpoint-deficient and G1 checkpoint-competent cells. Cancer Research, 55, 1639-1642. doi:10.1016/0360-3016(95)97826-M

[11] Monks, A., Scudiero, D., Skehan, P., Shoemaker, R., Paull, K., Vistica, D., Hose, C., Langley, J., Cronise, P. and Vaigro-Wolff, A. (1991) Feasibility of a high-flux anticancer drug screen using a diverse panel of cultured human tumor cell lines. Journal of the National Cancer Institute, 83, 757-766. doi:10.1093/jnci/83.11.757

[12] Siu, W.Y., Yam, C.H. and Poon, R.Y. (1999) G1 versus G2 cell cycle arrest after adriamycin-induced damage in mouse Swiss3T3 cells. FEBS Letters, 461, 299-305. doi:10.1016/S0014-5793(99)01481-7

[13] Bode, A.M. and Dong, Z. (2007) The enigmatic effects of caffeine in cell cycle and cancer. Cancer Letters, 247, 2639. doi:10.1016/j.canlet.2006.03.032 